\author{
Barbara ZAJAc ${ }^{1}$ \\ Michał POMORSKI ${ }^{2}$
}

\title{
OKREŚLANIE OPTYMALNEGO UDZIALU OKIEN W BUDYNKU MIESZKALNYM
}

\begin{abstract}
W pracy przedstawiono obliczenia energochłonności budynku mieszkalnego przy różnych udziałach okien w przegrodach zewnętrznych budynku. Obliczenia zostały wykonane według metodologii stosowanej podczas wyznaczania charakterystyki energetycznej budynków. Podjęto próbę określenia optymalnego udziału powierzchni przezroczystych $\mathrm{w}$ przegrodach zewnętrznych dla różnych orientacji względem stron świata oraz różnych parametrów termicznych przegród. Uzyskane wyniki porównano z wymaganiami technicznymi stawianymi oknom, dotyczącymi ochrony cieplnej i doświetlenia pomieszczeń.
\end{abstract}

Słowa kluczowe: zyski solarne, energochłonność, warunki techniczne, przegroda budowlana

\section{Wstęp}

Jednym z największych konsumentów energii w krajowym bilansie energetycznym jest energetyka komunalna. Według danych Głównego Urzędu Statystycznego [2] w gospodarstwach domowych zużywa się ok. 30\% całkowitej ilości energii końcowej, z czego większość (ok. 85\%) jest przeznaczana na ogrzewanie budynków i przygotowanie ciepłej wody użytkowej [4]. Jednocześnie w ostatnich latach zaobserwowano znaczny wzrost cen nośników energii, co powoduje zwiększanie kosztów ogrzewania budynków. Jednym ze sposobów ograniczania kosztów ogrzewania jest wykorzystanie zysków ciepła, głównie tych pochodzących z promieniowania słonecznego. Zyski te można skutecznie wykorzystać $\mathrm{w}$ wyniku zoptymalizowania powierzchni przegród przezroczystych i ich usytuowania na etapie projektowania budynku.

\footnotetext{
${ }^{1}$ Barbara Zając, Politechnika Wrocławska, e-mail:173344@ student.pwr.edu.pl.

2 Autor do korespondencji/corresponding author: Michał Pomorski, Politechnika Wrocławska, ul. Wybrzeże Wyspiańskiego 27, 50-370 Wrocław, tel.: (71) 3203605, e-mail: michal.pomorski@pwr.edu.pl.
} 


\section{Przepisy prawne dotyczące przegród przezroczystych w budynkach}

Przegrody przezroczyste, do których można zaliczyć okna, spełniają głównie funkcję elementów doświetlających światłem dziennym pomieszczenia w budynku oraz poprawiających walory estetyczne. Cechują się zazwyczaj gorszymi wskaźnikami ochrony cieplnej niż przegrody nieprzezroczyste. To właśnie doświetlenie światłem dziennym i ochrona cieplna budynku są kryteriami, które określają zakres powierzchni okien w danym budynku. Polskim przepisem prawnym, który ujmuje te wymagania, jest Rozporządzenie Ministra Infrastruktury w sprawie warunków technicznych, jakim powinny odpowiadać budynki $\mathrm{i}$ ich usytuowanie. Zgodnie $\mathrm{z}$ tym rozporządzeniem minimalna powierzchnia, jaką muszą posiadać okna, aby doświetlić pomieszczenie światłem dziennym, stanowi 1/8 pola powierzchni pomieszczenia. Kryterium ochrony cieplnej budynku określa maksymalną wartość współczynnika przenikania ciepła okien, który nie może być większy niż $1,3 \mathrm{~W} / \mathrm{m}^{2} \cdot \mathrm{K}$, oraz ich maksymalną powierzchnię w przegrodzie. Dla okien o współczynniku przenikania ciepła nie mniejszym niż $0,9 \mathrm{~W} / \mathrm{m}^{2} \cdot \mathrm{K}$ jest ona definiowana jako funkcja pola powierzchni rzutu poziomego wszystkich kondygnacji [6]:

$$
A_{0 \text { max }}=0,15 A_{z}+0,03 A_{w}
$$

gdzie: $A_{z}$ - suma pól powierzchni rzutu poziomego wszystkich kondygnacji nadziemnych (w zewnętrznym obrysie budynku) w pasie o szerokości $5 \mathrm{~m}$ wzdłuż ścian zewnętrznych,

$A_{w}$ - suma pól powierzchni pozostałej części rzutu poziomego wszystkich kondygnacji po odjęciu $A_{z}$.

Dla okien o współczynniku przenikania ciepła mniejszym niż $0,9 \mathrm{~W} / \mathrm{m}^{2} \cdot \mathrm{K}$ maksymalna powierzchnia okien nie jest definiowana. Jeżeli przyjmie się, że budynek jest parterowy, o wymiarach $10 \times 10 \mathrm{~m}$, wysokości $2,5 \mathrm{~m}$ i jednym tylko pomieszczeniu, to zgodnie $\mathrm{z}$ warunkami technicznymi powierzchnia okien o współczynniku przenikania ciepła większym lub równym $0,9 \mathrm{~W} / \mathrm{m}^{2} \cdot \mathrm{K}$ musiałaby się zawierać pomiędzy 12,5 (warunek doświetlenia pomieszczeń) a 15\% (warunek ochrony cieplnej) pola powierzchni przegród zewnętrznych. Jest to dość wąski zakres, niedający zbyt dużego pola manewru. Dodatkowo, jak łatwo zauważyć, przepisy prawne zawarte w Warunkach Technicznych nie uwzględniają usytuowania przegrody względem stron świata, co jest niezwykle ważne z punktu widzenia pozyskiwania ciepła pochodzącego z promieniowania słonecznego. Może się bowiem okazać, że przy usytuowaniu okien od strony o dużym nasłonecznieniu zyski ciepła będą znacząco redukowały straty ciepła przez okna spowodowane ich gorszą izolacyjnością termiczną $[1,3]$. 
W pracy [2] autorzy wykonali bilans ciepła dla przegrody budowlanej, w której udział części przezroczystej zmieniał się od 0 do 100\% dla różnych parametrów termicznych przegród przezroczystej i nieprzezroczystej oraz usytuowania względem różnych stron świata. Wyniki obliczeń pokazały możliwość wykorzystania słonecznych zysków ciepła dla okien o współczynniku przenikania ciepła mniejszym niż $1,8 \mathrm{~W} / \mathrm{m}^{2} \cdot \mathrm{K}$, zwłaszcza od strony południowej. Ta analiza posiadała jednak wiele uproszczeń, tj. brak uwzględnienia wewnętrznych zysków ciepła, założenie stuprocentowej efektywności wykorzystania zysków ciepła oraz wykonywanie obliczeń tylko dla przegrody budowlanej, a nie dla całego budynku.

\section{Obliczenia energochłonności analizowanego budynku}

W niniejszej pracy zostały przedstawione wyniki obliczeń energochłonności budynku o różnych parametrach termicznych okien i przegród zewnętrznych. Do analizy wybrano budynek parterowy o podstawie kwadratowej i boku $10 \mathrm{~m}$. Wysokość kondygnacji to 2,5 m. Energochłonność budynku wyznaczono zgodnie z metodologią obliczania charakterystyki energetycznej budynku [5]. Wynikowym obliczanym parametrem była jednostkowa ilość energii cieplnej niezbędna do pokrycia potrzeb ogrzewczych budynku w ciągu sezonu grzewczego, definiowana jako:

$$
q_{h}=\frac{1}{A_{f}} \sum_{1}^{12}\left(Q_{H, h t}-\eta_{H, g n} \cdot Q_{H, g n}\right)
$$

gdzie: $q_{h} \quad$ - jednostkowa ilość energii cieplnej niezbędna do pokrycia potrzeb ogrzewczych budynku,

$A_{f} \quad$ - powierzchnia ogrzewana budynku,

$Q_{H, h t}$ - miesięczne straty ciepła na ogrzewanie i wentylację,

$Q_{H, g n}$ - miesięczne zyski ciepła wewnętrzne i od słońca,

$\eta_{H, g n}-$ współczynnik efektywności wykorzystania zysków w trybie ogrzewania.

Parametry okien przyjęte do obliczeń:

- współczynnik przenikania ciepła okien $U_{o k}=1,5-1,8 \mathrm{~W} / \mathrm{m}^{2} \cdot \mathrm{K}$,

- udział pola powierzchni przeszklonej do powierzchni całkowitej $C=0,7$,

- współczynnik przepuszczalności energii promieniowania $g=0,75$,

- współczynnik zacienienia budynku $Z=0,8-1,0$.

Współczynniki przenikania ciepła przyjęte do obliczeń:

- ścian zewnętrznych $U_{s c}=0,20-0,30 \mathrm{~W} / \mathrm{m}^{2} \cdot \mathrm{K}$,

- podłogi na gruncie $U_{p}=0,20-0,45 \mathrm{~W} / \mathrm{m}^{2} \cdot \mathrm{K}$,

- stropu $U_{s t r}=0,15-0,25 \mathrm{~W} / \mathrm{m}^{2} \cdot \mathrm{K}$,

- budynku $C_{m}=10 \mathrm{MJ} / \mathrm{K}$. 
Obliczenia wykonano dla udziałów okien zmieniających się w przedziale 0-1. Przyjęto, że budynek jest zlokalizowany w drugiej strefie klimatycznej, w pobliżu stacji meteorologicznej Wrocław. Dane meteorologiczne pobrano ze strony Ministerstwa Infrastruktury i Rozwoju [7]. Na wykresach 1-6 przedstawiono wybrane wyniki obliczeń jednostkowego zapotrzebowania na ciepło do celów grzewczych przy różnych udziałach okien w przegrodzie zewnętrznej budynku. Obliczenia zostały przeprowadzone $\mathrm{z}$ założeniem zmienności udziału okna w przegrodzie dla jednej orientacji względem stron świata, natomiast dla pozostałych stron świata udział ten był stały i wynosił $20 \%$.

$\mathrm{Na}$ przedstawionych charakterystykach można zauważyć, że energochłonność budynku jest bardzo uzależniona od parametrów ochrony cieplnej wszystkich przegród oraz udziału i orientacji okien. Zazwyczaj jest obserwowany spadek energochłonności wraz ze zwiększaniem udziału okien w przegrodach umiejscowionych od strony południowej (rys. 1., 4.). Zwiększanie udziału okien w przegrodach od strony północnej powoduje wzrost potrzeb grzewczych budynku (rys. 3., 6.). Dla elewacji wschodniej i zachodniej energochłonność może zarówno wzrastać, jak i spadać wraz ze zwiększaniem powierzchni okien, co jest zależne od wartości parametrów ochrony cieplnej okien i przegród nieprzezroczystych (rys. 2., 5.). Otrzymywane wyniki nie są zgodne z udziałami okien określanymi przez przepisy prawne. Jest to obserwowane zwłaszcza przy usytuowaniu okien od stron świata o dużym nasłonecznieniu. Znacząco niekorzystnie na wyniki energochłonności wpływa zacienienie okien.

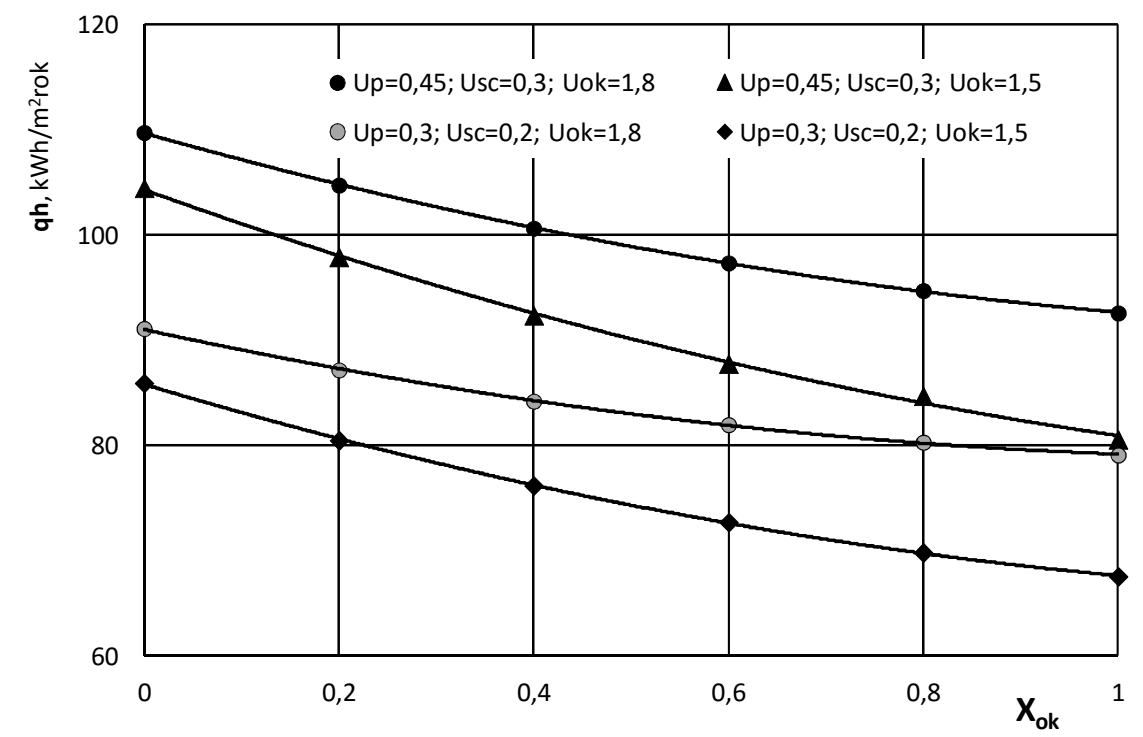

Rys. 1. Zapotrzebowanie na ciepło dla budynku $\left(U_{s t r}=0,25\right)$ - strona południowa

Fig. 1. Heat demand for a building $\left(U_{s t r}=0,25\right)$ - southern side 


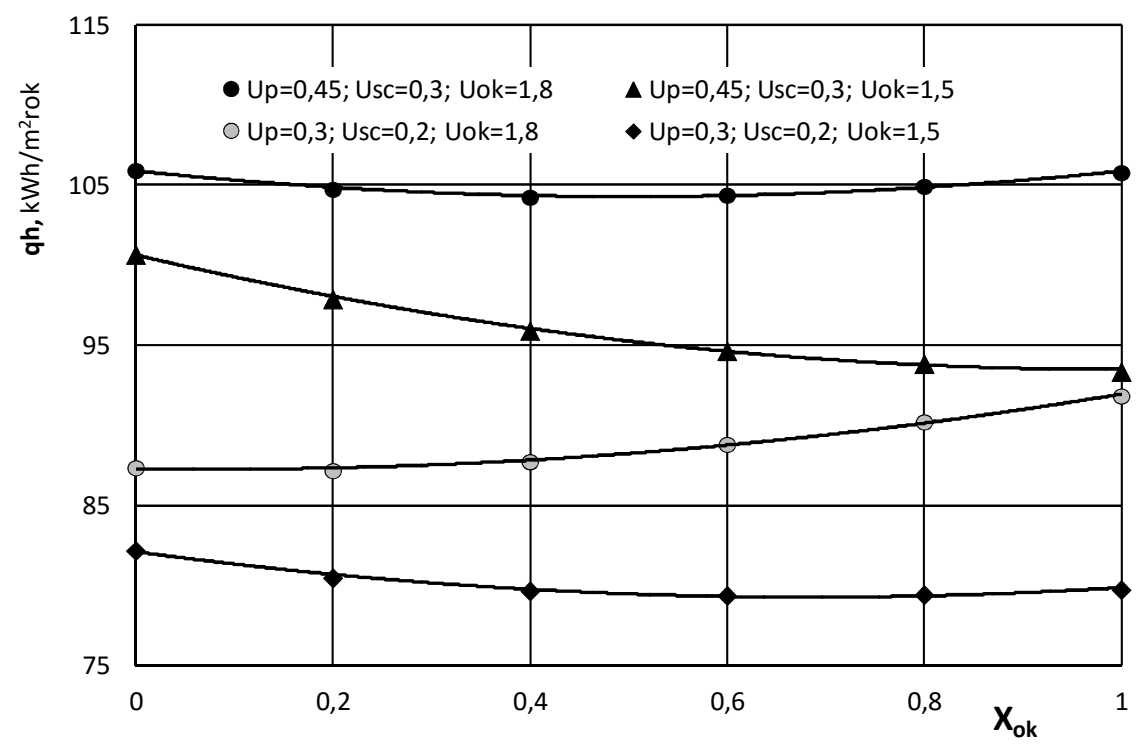

Rys. 2. Zapotrzebowanie na ciepło dla budynku $\left(U_{s t r}=0,25\right)$ - strona wschodnia

Fig. 2. Heat demand for a building $\left(U_{s t r}=0,25\right)$ - eastern side

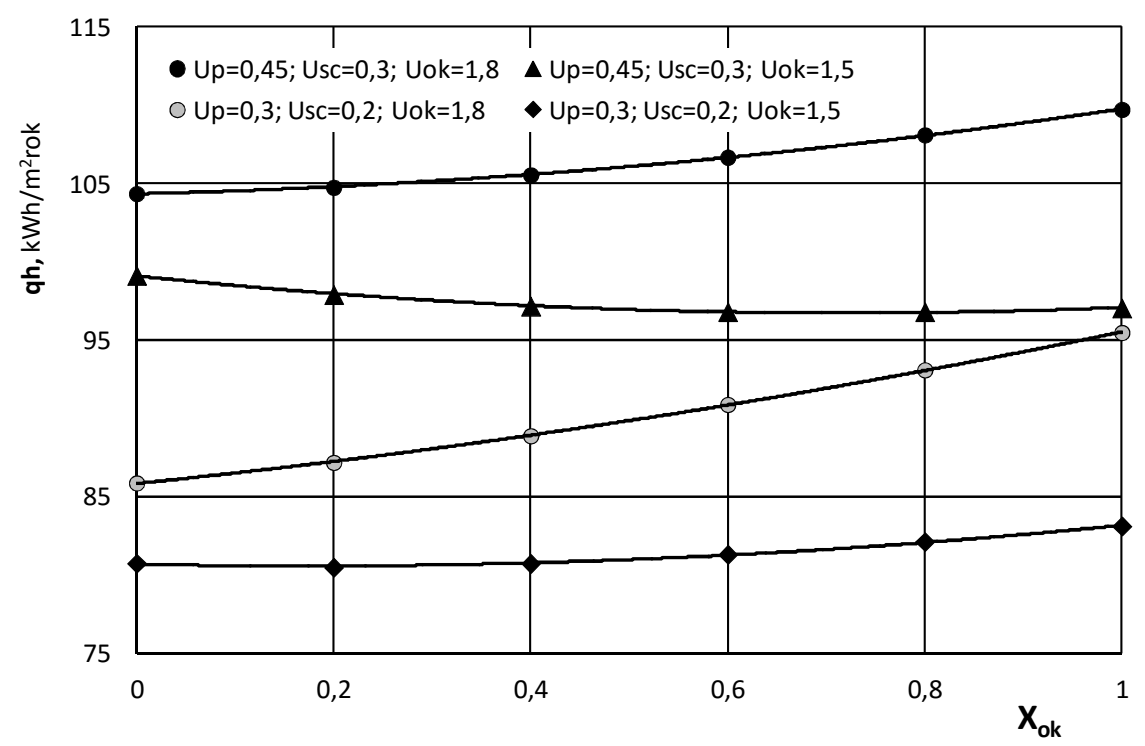

Rys. 3. Zapotrzebowanie na ciepło dla budynku $\left(U_{s t r}=0,25\right)$ - strona północna

Fig. 3. Heat demand for a building $\left(U_{s t r}=0,25\right)$ - northern side 


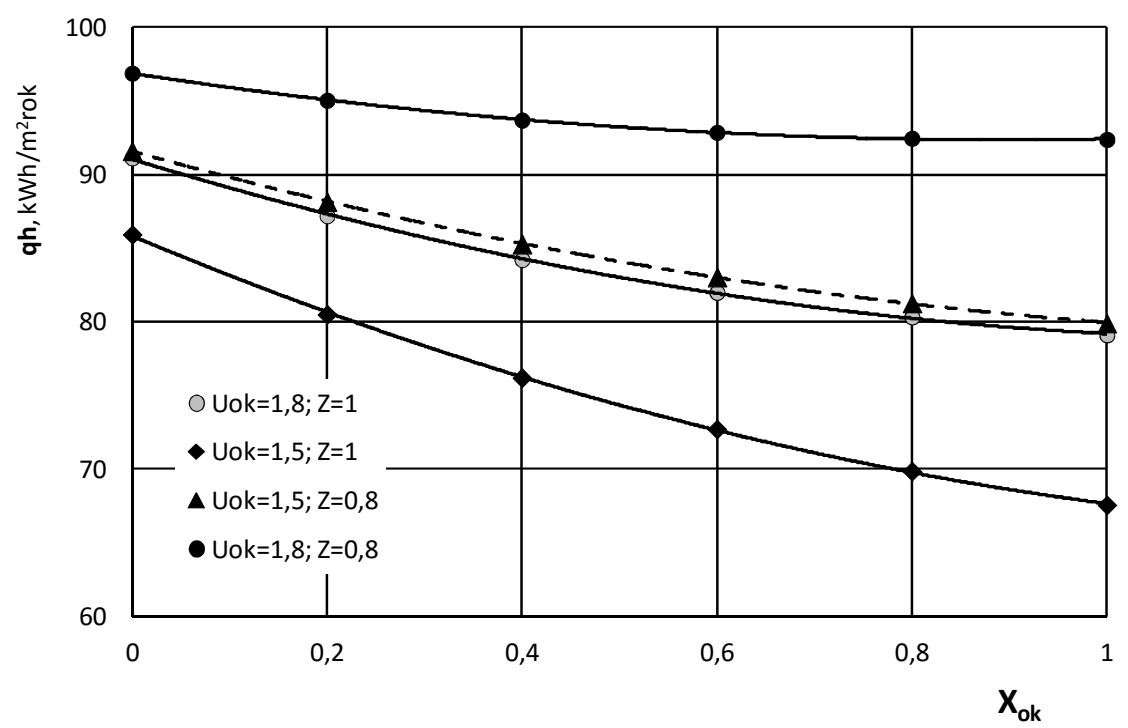

Rys. 4. Zapotrzebowanie na ciepło dla budynku $\left(U_{p}=0,3 ; U_{s c}=0,2 ; U_{s t r}=0,35\right)$ - strona południowa

Fig. 4. Heat demand for a building $\left(U_{p}=0,3 ; U_{s c}=0,2 ; U_{s t r}=0,35\right)$ - southern side

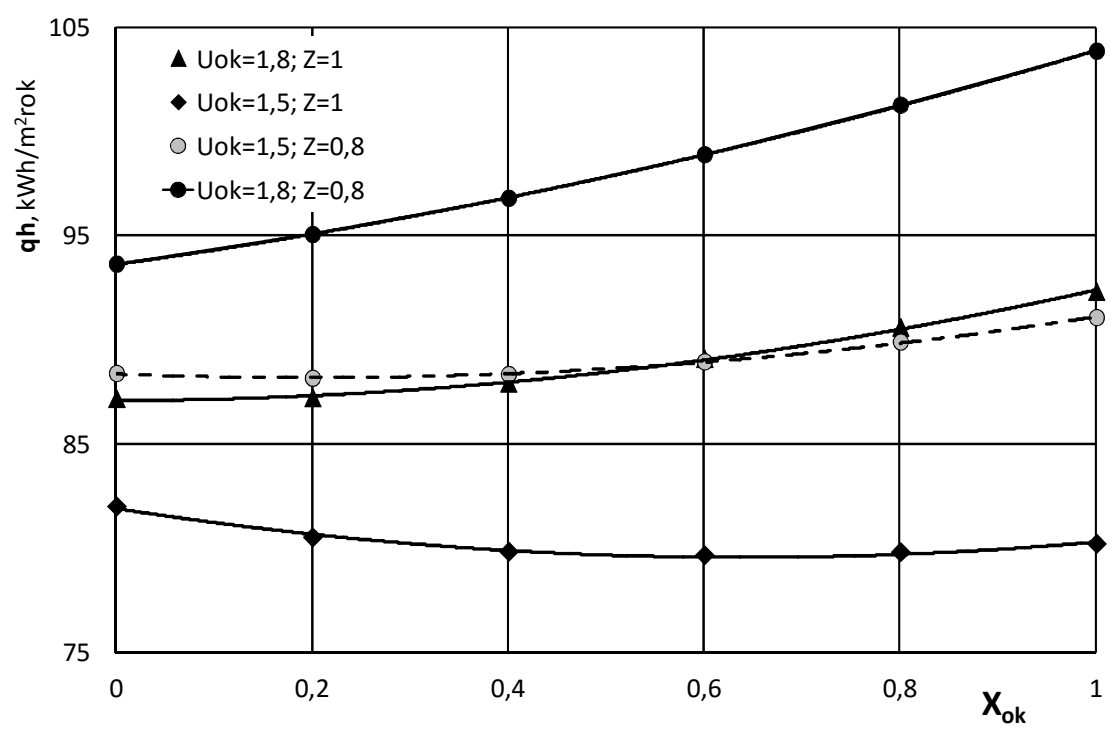

Rys. 5. Zapotrzebowanie na ciepło dla budynku $\left(U_{p}=0,3 ; U_{s c}=0,2 ; U_{s t r}=0,35\right)-$ strona wschodnia

Fig. 5. Heat demand for a building $\left(U_{p}=0,3 ; U_{s c}=0,2 ; U_{s t r}=0,35\right)$ - eastern side 


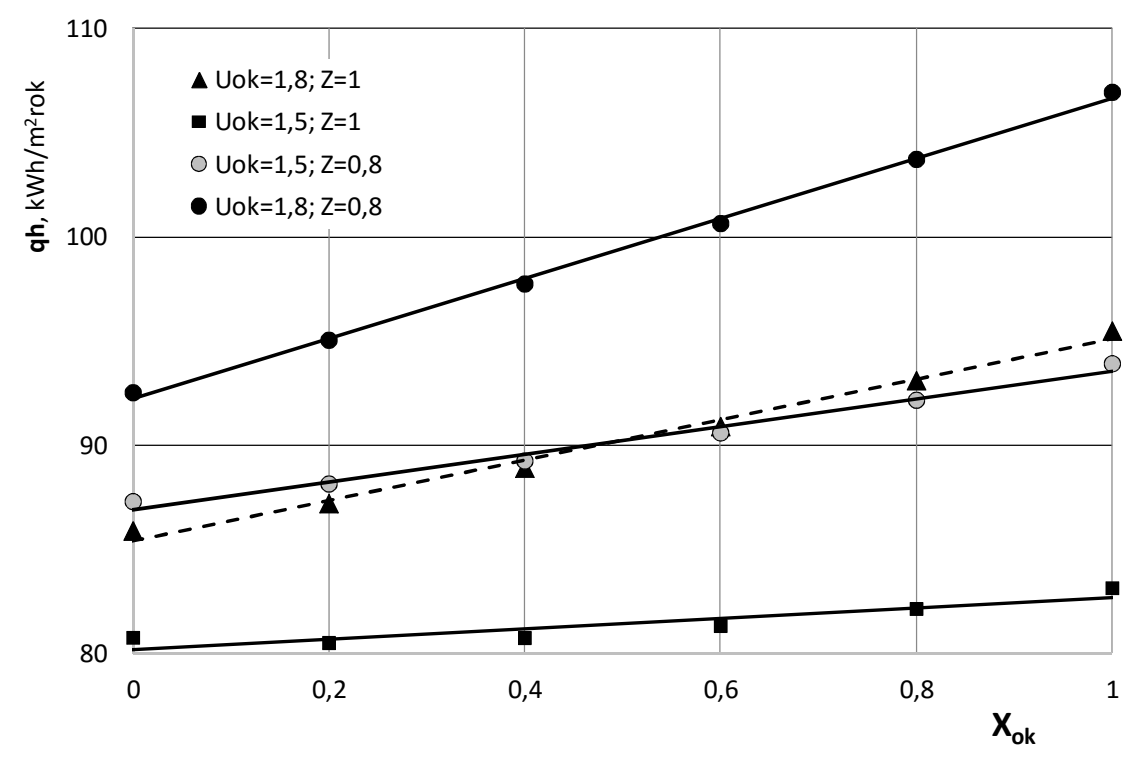

Rys. 6. Zapotrzebowanie na ciepło dla budynku $\left(U_{p}=0,3 ; U_{s c}=0,2 ; U_{s t r}=0,35\right)-$ strona północna

Fig. 6. Heat demand for a building $\left(U_{p}=0,3 ; U_{s c}=0,2 ; U_{s t r}=0,35\right)$ - northern side

\section{Podsumowanie}

W pracy podjęto próbę optymalizacji powierzchni okien w budynku mieszkalnym w sezonie grzewczym. Na podstawie przeprowadzonych obliczeń można wysnuć wniosek, że istnieje potrzeba optymalizacji powierzchni okien w przegrodach zewnętrznych budynków z uwzględnieniem parametrów ochrony cieplnej przegród oraz ich orientacji względem stron świata. Zazwyczaj jest obserwowana tendencja do zmniejszania energochłonności wraz ze zwiększaniem udziału okien od strony południowej oraz do zwiększania energochłonności przy rosnącym udziale okien od strony północnej. Ze względu na różnorodność konstrukcji budowlanych wskazane byłoby indywidualne podejście do każdego obiektu w celu określenia optymalnej powierzchni okien. Celowe wydaje się również rozwinięcie analizy na sezon letni, aby uwzględnić konieczność poniesienia nakładów energetycznych na chłodzenie pomieszczeń, do których docierają solarne zyski ciepła. Dopełnieniem tej optymalizacji byłoby również wykonanie analizy ekonomicznej na poziomie inwestycyjnym.

\section{Literatura}

[1] Duda L.: Optymalizacja parametrów energetycznych okien, Profiokno, 8 (2011), 10-11.

[2] Efektywność wykorzystania energii w latach 2001-2013, Główny Urząd Statystyczny, Warszawa 2013. 
[3] Matusiak W.: Optymalizacja energetycznych okien nowych i wymienianych. Bilans energetyczny okien w sezonie grzewczym, Twój Filar, 1 (2012), 15-18.

[4] Pomorski M., Pietrowicz S.: Określanie optymalnego udziału powierzchni przegrody przezroczystej w całkowitej powierzchni przegrody budowlanej, Polska Energetyka Słoneczna, 2-4 (2010), 12-16.

[5] Rozporządzenie Ministra Infrastruktury w sprawie metodologii obliczania charakterystyki energetycznej budynku i lokalu mieszkalnego lub części budynku stanowiącej samodzielną całość techniczno-użytkową oraz sposobu sporządzania i wzorów świadectw ich charakterystyki energetycznej, www.mir.gov.pl.

[6] Rozporządzenie Ministra Transportu, Budownictwa i Gospodarki Morskiej w sprawie warunków technicznych, jakim powinny odpowiadać budynki i ich usytuowanie.

[7] Typowe lata meteorologiczne i statystyczne dane klimatyczne dla obszaru Polski do obliczeń energetycznych budynków, www.mir.gov.pl.

\section{DETERMINATION OF OPTIMAL WINDOW SHARE IN A RESIDENTIAL BUILDING}

\section{S u m m a r y}

This paper presents the calculation of the energy consumption of a residential building for different shares of windows area in the external walls of the building. The calculations were made according to the methodology used for determining the energy performance of buildings. Optimization of the share of transparent surfaces in the external walls, taking into account various orientations, and different thermal parameters of partitions were also here presented. The results of building energy consumption calculations referring to different shares of windows area were compared with the permissible technical requirements for windows.

Keywords: solar gains, energy consumption, technical requirements, building partition

DOI: $10.7862 / \mathrm{rm} .2015 .27$

Otrzymano/received: $14.09 .2014 \mathrm{r}$.

Zaakceptowano/accepted: $22.03 .2015 \mathrm{r}$. 